\title{
Gender Bias in the Iranian High School EFL Textbooks
}

\author{
Mohadeseh Amini (Corresponding author) \\ Department of English Literature, Karaj Branch, Islamic Azad University, Karaj, Iran. \\ E-mail:m.amini@kiau.ac.ir
}

Parviz Birjandi

Department of English Literature, Research \& Science Branch

Islamic Azad University, Tehran, Iran

Received: September 13, 2011

Accepted: November 22, 2011

Published: February 1, 2012

doi:10.5539/elt.v5n2p134

URL: http://dx.doi.org/10.5539/elt.v5n2p134

\begin{abstract}
Gender bias is unfortunately still present in many societies especially the developing countries. Such prejudice is in most cases in favor of males and against females. While females nowadays comprise a great majority of the work force all around the world, they are still being looked upon as the weaker sex associated with stereotypical roles as stay-at-home mothers whose main task is to breed children, wash the dishes, etc.

Such prejudice if present in a society gets manifested in its EFL/ ESL materials. The main purpose of the present study is to examine the extent and types of gender bias in two of the Iranian mostly used EFL textbooks at the high school level. Sexism will be investigated in five categories of visibility, firstness, generic masculine constructions, sex-linked occupations and activities. The findings are expected to raise awareness regarding sexist practices in EFL material developers, teachers and learners.
\end{abstract}

Keywords: Gender bias, Visibility (omission), Firstness, Generic masculine generics

\section{Introduction}

The present study has been a by-product of another research currently being carried out by the same researchers, namely Differential Item Functioning (DIF) Analysis of the Iranian Entrance University Examinations. When important decisions are made based on test scores, it is critical to avoid bias, which may unfairly influence examinees' scores. Bias in a test is the presence of some characteristic of an item that results in differential performance for individuals of the same ability but from different ethnic, age, sex, academic, cultural or religious groups. Bias is often attributed to construct-irrelevant dimensions that differentially affect the test scores of different groups of examinees. Sadly so far, the analyses of the results in the study just referred to have revealed considerable $D I F$ across different examinee groups.

As far as gender bias is concerned, which is the main focus of the present paper at the same time, the Iranian entrance university examinations is highly and unfairly biased against women and the main reason for that is undoubtedly the existence of gender-biased high school EFL materials. So the present paper is intended to call the attention of material developers and decision makers in Iran to take action against gender bias in high school EFL materials. Since users of any test, including entrance university examinations, must be confident that scores of all student subgroups can be interpreted in a similar way. The main concern here is perhaps the substantial difference in the mean test scores of different subgroups. Users of the instrument might worry whether such differences are caused by the differences in the skills measured or are an artifact of the instrumentation procedure. In other words, the question here is whether the test measures for various subgroups what it claims to measure!

Studies similar in tone to the present one are not new in our country and already date back to almost two decades ago. However they might not have been forceful enough to be noticed and attended to by the authorities. The researchers here would like to ask their colleagues to take part in a serious campaign against gender bias in the Iranian high school EFL materials and replicate similar studies in different voices hoping the echo would get strong enough to be noticed by the decision makers.

Language is not only a means of communication but also a reflection of the political, social and cultural attitudes. Certain language can help reinforce the idea of male superiority and female inferiority. What is now termed sexist 
language often suggests an inherent male dominance and superiority in many fields of life. Sexist language is language that expresses bias in favor of one sex and thus treats the other sex in a discriminatory manner. The word sexism was originally coined to refer to ideas and practices that downgrade women relative to men (Cameron 1985). Nowadays, though, it is used to refer to practices that unfairly treat either sex.

One of the flourishing areas of sociolinguistics in the last decades has been that of language and gender motivated by feminist movements arguing over how language is used as an instrument to discriminate and dominate females (Key 1975; Lackoff 1975). Drawing from linguistic researches on gender representation in the English Language, a large number of studies have been directed towards the investigation of gender bias in language teaching materials, especially in EFL textbooks.

In the EFL context, within the classroom environment it is important that teachers pay attention to gendered language since language is not value-free, lifeless, or free of political bias (Beebe 1996 in Cook, 2005). The attitudes repeatedly expressed in books and other media might gradually distort learners' perceptions regarding stereotypes and myth about either sex. Students learning a foreign language might internalize sexist male and female representations reflected in their textbooks. It is thus possible that exposure to gender-biased texts and materials may influence females' behavior in such a way as to restrict their social, behavioral, and linguistic roles.

The present paper studies gender bias in two of the widely used Iranian EFL textbooks at the high school level compiled by the Textbook Curriculum Development and Planning Department of the Ministry of Education of the Islamic Republic of Iran. The premise of this investigation is that understanding sexism at the school level is an important, necessary, and often neglected aspect of curricular reform efforts and that such awareness would render more gender unbiased and valid tests. The focus of this study will be the investigation of gender bias in five categories of visual and textual presentation of males and females (visibility/ omission), firstness, masculine generic constructions, occupations, and activities performed by either sex.

\section{Previous Studies}

Since 1970s, researchers worldwide have shown interest in the study of gender bias in ESL/ EFL materials. Graham (1975) was among the first to investigate sexism in a school children's dictionary. She found that the nouns used to describe male activities were seven times as many as the nouns used for female activities. In addition, the visibility of males to females was four to one.

In Nilsen's (1977) analyses of a standard dictionary, it was revealed that the visibility of men to women was three to one and that there were five times as many words for things named after males than after females. And the words referring to females were mainly passive compared against the active words used to refer to males.

Coles (1977) studied five series of educational materials in which as the results firmly indicated males outnumbered females. Furthermore, females were mainly depicted as stay-at-home housewives and mothers whereas males appeared in a variety of activities and jobs ranging from drivers to doctors.

Hoomes (1978) studied twenty eight high school anthologies. The results indicated that the visibility of females to males was one to three and that men outnumbered women by far in activities and occupations.

Gerrity (1978) examined a series of primary reading passages in which the stories were absolutely male-oriented and male-referenced.

Hartman and Judd (1978) explored sexism in ESL materials in their Sexism and TESOL Materials. In their review of several then popular ESL textbooks, they investigated the treatment of males and females in five categories of visibility, firstness, occupational roles, nouns used to refer to either sex and masculine generic constructions. In all the categories studied, both in texts and illustrations women suffered from under-representation with only one exception concerning 'firstness' where the female counterpart was ordered first (ladies and gentlemen).

Hellinger (1980) examined random extracts from three English textbooks. Males once more outnumbered females in visibility and initiation.

Porreca (1984) studied sexism in some of the then current ESL textbooks in six categories of occurrence (both visual and textual), occupational roles, nouns, firstness, masculine generic constructions, and adjectives associated to either sex. In every category of the study, there was evidence that five years after Hartman and Judd's study, sexism continued to flourish in ESL materials. Although females comprised slightly over half the population of the United States, they were depicted or mentioned only half as often as males in both texts and illustrations (Porreca 1984: 718).

Poulou (1997) ran a thorough quantitative and qualitative examination of a number of dialogues. Based on her findings, whereas male dominance was still prevalent, females were dominant only quantitatively as far as visibility 
was concerned.

Johansson and Bachelder (2005) studied four EFL series in terms of four typologies including dialogue initiation, turn taking, number of characters, and number of words used. In the first series Time (1996-98), men were overrepresented in three out of the four typologies studied. In the second series Wings (2001-03), men overrepresented women in two out of the four typologies. In the next two series Happy (2004-06) and What's up (2004-07), women overrepresented men in three out of four and all typologies respectively.

Ansary and Babaii (2005) performed two types of analyses to examine the manifestation(s) of sexist attitudes and values in two textbooks (Right Path to English $I \& I I$ ). In their quantitative analysis, they investigated sex visibility in both texts and illustrations and female/male topic presentation in dialogs and reading passages. And in their qualitative analysis, they studied sex-linked job possibilities, sex-based activity types, stereotyped sex, firstness and masculine generic conception. Results revealed that the books studied were biased in terms of all the categories investigated.

Lee and Collins (2006) studied gender representation of English textbooks in Hong Kong. Of the twenty recent and earlier books studied, only 6 were reported in their study since their investigations were still on the way. The examined sexism in seven categories including omission (visibility), roles, masculine generic constructions, titles, order of appearance, pictorial representation of both genders and their roles and activities. The comparison of sexism in recent and earlier textbooks indicated that textbook writers had become more conscious regarding sexist practices in some categories. Their study however differed from other studies since they included the investigation of semantic as well as domestic and social roles in their study. Based on the Systemic-Functional concept of transitivity and its primary semantic categories of participant and process (Lock 1996; Halliday 2004), they investigated gender bias across five semantic processes (material, verbal, relational, mental and existential) and five categories of participants. Close examination of various semantic roles revealed subtle gender stereotyping and semantic role shifts in recent versus earlier textbooks (Lee and Collins 2006).

Mineshima (2008) studied gender representations in an EFL textbook Birdland Oral Communication I to investigate how it portrays the two genders. She examined sexism in three categories including number of females versus males, number of their utterances and firstness. In all categories studied, females were under-represented and overloaded with traditional stereotypical roles whereas males appeared only as cooperative.

Mukundan and Nimehchisalem (2008) studied the representation of gender in some English language textbooks in Malaysia. The results indicated significant gender bias against both sexes with males outnumbering females in texts and illustrations and males mainly associated with negative traits. However, discourse wise, males dominated females. They spoke more, talked first, and were more visible.

Vogli (2009) investigated gender representation in New Success at First Certificate in six categories of omission, occupation, F/M stereotypes, masculine generic constructions, firstness and adjectives associated to each sex. Despite the efforts the writers had made to portray women and men equally, the findings indicated that men were upfront and women followers. Sometimes they (females) were protagonists in a 'man's world' [but that looked like sugar coat] (Vogli 2009).

\section{Method}

\subsection{Instruments}

The instruments used in this study consisted of the 2010-11 Iranian English textbooks for the second and third grades of high school compiled by the Textbook Curriculum Development and Planning Department of the Ministry of Education of the Islamic Republic of Iran.

Book II consisted of seven lessons and Book III of six lessons, each beginning with a new words section, accompanied by a reading passage. After the reading text, comprehension questions followed in forms of True/False, Complete the sentences, etc. Then, there came the speaking and writing sections in different exercise patterns. Other sections which could be noticed were language functions, pronunciation practice, vocabulary review or drill and $a$ vocabulary list.

Both at the beginning and the end of each book, there were some review exercises which were excluded from the gender bias analyses in the present study because they were intended to check the mastery of the students over the EFL materials covered so far since the beginning of the Iranian EFL instruction (junior high school).

\subsection{Design}

The present study is mainly a descriptive research including quantitative and qualitative investigations of the visibility (frequency and nature) of the two genders across five categories including omission, firstness, masculine 
generic constructions, occupations and activities in two of the Iranian EFL textbooks currently practiced at the high school level.

\subsection{Procedure}

In the present textbook gender bias research, sexism has been studied across five categories including visibility, firstness, masculine generic constructions, occupations and activities associated with either sex in the following order.

First, the visibility of females and males in both texts and illustrations was investigated. Female/male firstness -- the number of times when males or females were presented first in texts - was also recorded. To witness whether masculine generic constructions were truly generic (including both sexes) or merely male referenced, the association between all masculine generic nouns and pronouns and their referents was determined as well.

In addition, occupations in which females and males were depicted were identified and compared against. Finally, the type of illustrated and textual activities in which females and males participated was investigated.

\section{Findings}

\subsection{Visibility}

One of the main manifestations of sexism in textbooks has always been female/ male visibility also called omission. When females do not appear as often as males, the implicit message is that women are not as important as men, or that their accomplishments are not as worthwhile to mention as men's or that they themselves as human beings are not important enough to be included (Porreca 1984:706).

In Iran, according to census statistics, the number of females in recent years has consistently surpassed that of males. And for the textbooks here investigated to be authentic and sex fair, they should reflect such demographic pattern. To see whether this is reflected in the Iranian EFL textbooks or not, the number of textual and visual mentions of male and female characters was counted both in the second and third grade EFL Iranian textbooks at the high school level. Tables 1 and 2 below illustrate the findings.

As indicated in Table 1, it was found that there were 52 male $(80 \%)$ and 13 female $(20 \%)$ characters in Book II illustrations, and 76 female (18.8) and 329 male (81.2) characters in Book II texts. Things were not any better in Book III.

In Book III illustrations, out of 59 depictions, 37 (62.7) belonged to males and only 22 (37.3) to females. And in texts, the condition even got worse. Out of 229 mentions, only 38 (16.6) concerned females.

Both tables as presented here reinforce the assumption that women are underrepresented in terms of visibility in number in Iranian high school EFL textbooks in a way that does by no way reflect the reality.

\subsection{Firstness}

Firstness refers to the mention of men first in texts before women as if 'the masculine gender is more worthy than the feminine' (Poole 1946:21; cited in Eckert and McConnell-Ginet 2003:34).

In Iran, men in most cases come ahead of women in most social practices. When walking together for instance, women usually follow their men. In parties and public ceremonies, men are served first. In Iran, it is almost 'Gentlemen first, ladies next!'

To investigate gender firstness in Iranian high school textbooks, the present study examined all the instances in the two textbooks in which the two genders were mentioned together and checked which appeared first. Here are the findings.

In Book II, for 12 (85.71\%) first mentions of males, there were only 2 (14.28) first mentions of females.

In Book III, there was one out of one instance of male firstness. As indicated in Tables 3 and 4, men in majority of the cases are mentioned first. Such subordination of females as mentioned earlier is deeply rooted in the Iranian culture.

\subsection{Masculine Generic Constructions}

One other manifestation of sexism is the use of the masculine as generic rooted in the grammar of the English language itself. In most cases where words like man, person, etc. and pronouns such as everybody, somebody, etc. are used in EFL textbooks, people hardly ever conceptualize females when reading such constructions (Porreca 1984). Quite recently, however, masculine generics are being avoided in EFL/ ESL textbooks. One strategy is to use paired pronoun expressions such as he/she, him/her, his/her, and s/he.

To investigate this issue, all occurrences of generic constructions were identified and analyzed to see whether 
masculine generic constructions were truly generics (including both females and males) or exclusively male referenced.

In Book II (page 87), there was only one case of a masculine generic construction that was definitely male referenced as presented below:

If someone asks you "where are you going?", you, ............ .

a. should give a true answer

b. should tell him where you are actually going

c. don't have to tell him where you are going

d. can give a quick reply

And in Book III, there were four instances of masculine generic constructions which were all male-referenced:

- $\quad$ This education should prepare the person for the job he can do best. (p. 24)

- When a person heard a voice speaking over the telephone from miles away, he was too exited to say 'How do you do?' or 'Good morning'. (p. 67)

- $\quad$ And when someone fasts, it means he doesn't eat. (p. 68)

- A pilot must do his work with great ...... (p. 93)

\subsection{Occupation}

The depiction of males and females in traditionally stereotypical biased occupations can be another reflection of sexism in EFL textbooks. Table 5 below lists various occupations female and male characters were engaged in as far as texts and pictures were concerned in book II.

Of the 19 (not considering the number of times an occupation was repeated) occupations either mentioned in texts or illustrated in pictures in Book II, 17 different jobs such as engineers, bus drivers, police officers, doctors and bosses belonged to men and in only 2 women were stereotypically depicted (either as teachers or dress makers).

And in Book III, the ratio of appearance of females to males in both texts and illustrations (ignoring repetitions of the same occupation) was 3 to 13 . Here again, men were depicted in a variety of manly jobs including wrestlers, pilots, hunters, etc. And women played their ever traditional roles as nurses, teachers, and only once as doctors.

For the word, inventor, there was only one male mention displaying men as ever achievers.

\subsection{Activities}

Both men and women should be shown cleaning, cooking, making household repairs, doing laundry, washing the car, and taking care of the children ... Males as well as females can be fearful, weak, mechanically inept, and illogical ... Males can be polite, cooperative, inactive, or neat. Because such characteristics are shared by males and females in reality, textbooks that classify them as 'masculine' or 'feminine' are misrepresenting reality (Scott 1981:139 in Mineshima 2008).

Contrary to the above generous quote, in Iran, men work out and women usually stay in, taking hold of the house choirs; taking care of the children, cooking meals, cleaning the house, washing the dishes, etc. The Iranian woman whether working out or staying at home is solely in charge of the household and his man if kind enough may cooperate sometimes.

To examine the presentation of females and males in Books II and III texts and illustrations, the activities in which females and males were depicted were located and studied. Tables 7 and 8 below display the findings.

As can be seen in Table 7, texts and pictures in Book II did reinforce traditionally gendered roles: there were only females engaged in various kinds of household chores. More importantly, of the 40 (not considering the number of repetitions) different activities illustrated in Book II, women were represented in only 13 including cooking the dinner, making the tea, etc.

In Book III as presented below in Table 8, the picture was not much different.

\section{Discussion and Conclusions}

The present study was an attempt to re-examine the second and third Iranian EFL textbooks at the high school level to investigate how they portray the two genders both in texts and illustrations after almost two decades of attention to the avoidance of gender biased materials. In every category there was evidence that sexism is still vividly practiced in Iranian EFL materials. 
Although females comprise over half the population of the Islamic Republic of Iran and are recently quite active in a variety of social roles, they suffered from low visibility both in texts and illustrations. It seems that the Islamic Iranian culture tends to leave no room for female visibility. A woman would better be invisible from the public eye as much as possible. Within the family, in many cases she is not welcome in men gatherings. Out, she still gets called using her eldest son's name (by her husband) rather than her own to avoid visibility. Upon her death, on her funeral notice her photo usually gets replaced with a flower.

Since textbooks reflect the social, cultural and religious ideologies and perceptions of their writers, it is no doubt there is not much room for women visibility in the Iranian EFL textbooks at the high school level.

Regarding firstness, again in majority of cases men were mentioned before women as is the case in the present Iranian culture especially in traditional families. In the two books studied here the masculine generic was in addition solely male referenced. Considering occupation, gender inequality was perceived even more. In the Islamic Republic of Iran today, women comprise a high percentage of the work force, and a great number of women are involved in highly skilled, professional jobs. However, in two Iranian high school textbooks investigated, this was not realistically depicted. Women were mainly illustrated in traditional sex-linked occupations such as teaching and doing household chores. This is far from the reality and equity. Currently women are proving more capable of the traditionally marked occupations, they are even seen as bus drivers in bigger cities where globalization is on the way!

Regarding the depiction of males/ females in activities, women were overall stereotyped as stay-at-home mothers and mainly engaged in household choirs including room cleaning, making the tea, and baking the cake and only sometimes had the chance of studying or watching $T V$. They were usually depicted as over-emotional and careless creatures that cried after TV films (Book II, p. 44) and more often than not lost things and only then busied themselves finding them (Book II, pp. 8 \& 34). Whereas Men were mostly busy playing football or Ping-Pong, reading newspapers, fixing the car, swimming, finding a new job, buying different things, etc. Males as breadwinners were always involved in buying things. The verb buy thus always collocated with a male agent.

Overall, the two textbooks investigated overrepresented male characters both linguistically and visually in frequency and order of occurrence, occupation, stereotypical activities, and the linguistic manifestation of masculine generic referents.

Sexism, it seems, is so deeply ingrained in our culture, our language, and our subconscious that it is difficult for us to avoid it in the production of language teaching materials (Florent et. al. 1989: 183 in Vogli 2009). And the question is how come gender bias reviews and critiques of the Iranian EFL materials throughout all these years have been left unnoticed and for almost 20 years or so the very same unmodified biased high school materials have been published and republished over and over again without the slightest change.

\section{Implications}

One implication of this study might be to raise awareness and consciousness in EFL material developers regarding gender prejudiced materials so as to help them initiate modifications regarding such inequities after almost 20 years of publishing the same gender-bias loaded materials with no change. Material developers and curriculum designers should pay attention to and consider the guidelines of gender-fair material development. There are several working guidelines in literature including On Balance (Florent et. al., 1994), Guidelines for Non-exist Use of Language in NCTE Publications, prepared by the National Council of Teachers of English (NCTE) in 1985 and the Guidelines for Gender-fair Use of Language published by The Women in Literacy and Life Assembly (WILLA) in 2002 (Mukundan and Nimehchisalem 2008).

Teachers, in addition, if made aware can deal with gender-biased materials logically and present them in an unbiased way (Sunderland et. al., 2001). They can select their own teaching materials with more care if allowed and if needed where the input of the course book reflects sexist practices or attitudes, ... comment on them. Critical reading and listening may thus become regular part of the suggested pedagogy' (Sunderland 1992:87). They should also beware not to attribute any specific roles, domestic or societal to either gender so as not to inculcate any preconceptions in the learners (Mineshima 2008).

\section{References}

Abraham, J. (1989). Teacher ideology and sex roles in curriculum texts. British Journal of Sociology of Education, 10, 33-51. http://dx.doi.org/10.1080/0142569890100103

Aitchison, J. (1991). Worrying about English. Moderna Sprak, 85, 113-120

Ansary, H., \& Babii, E. (2003). Subliminal Sexism in Current ESL/EFL Textbooks. Asian-EFL Journal, March 2003 
Ariew, R. (1982). The Textbook as curriculum. In T.V. Higgs (ed.), Curriculum, competence, and the foreign language teacher. Skokie, IL, National Textbook Company. pp. 11-33

Arnold-Gerrity, D. (1978). Sex stereotyping of women and girls in elementary textbooks and its implication for future work force participation. Paper presented at the North Central Sociological Association, Cincinnati, May 1978. (ERIC Document Reproduction Service ED 191087)

Babaii, E., \& Ansary, H. (2001). The structure of and stricture on TV Commercials in Iran. Paper presented at the 5th Conference on Theoretical and Applied Linguistics. Allame Tabataba'ii University, Tehran, March 13-15, 2001

Battistella, E. (1997). Guidelines for nonsexist usage. SECOL Review, 21, 104-25

Beebe, J. (1998). Sexist language and English as a foreign language: A problem of knowledge and choice. The Language Teacher, 22, 5

Beebe, J. D. (1996). Sexist language and teaching English as a foreign language. Gender Issues in Language Education, 100-113

Biber, D., Johansson, S., Leech, G., Conrad, S., \& Finegan, E. (1999). Longman grammar of spoken and written English. Essex: Longman.

Birjandi, P., \& Soheili, A. (1999). Right path to English I and II. Iran, Tehran: Ministry of Education, Center for the Publication of University Textbooks.

Britton, G., \& Lumpkin, M. (1977). For sale: Subliminal bias in textbooks. The Reading Teacher, 31(1), 40-45

Burchfield, R. (1981). The spoken word: A BBC guide. London: British Broadcasting Corporation.

Cameron, D., \& Coates, J. (1988). Some problems in the sociolinguistic explanation of sex differences. In J. Coates, \& D. Cameron (Eds.), Women in their speech communities. London: Longman. pp. 13-26

Caroll, D., \& Kowitz, J. (1994). Using concordancing techniques to study gender stereotyping in ESL textbooks. In Sunderland, J. (Ed.), Exploring gender: Questions and implications for English language education. London: Prentice Hall.

Carpenter, C. (1981). Exercises to combat sexist reading and writing. College English, 43, 293-300. http://dx.doi.org/10.2307/377243

Census and Statistics Department. (2002). 2001 population census: Main report, Vol 1. Hong Kong: Government Printer.

Chan, A. (2000). Keynote address. Proceedings: Hong Kong Perspectives on Beijing +5 . Hong Kong: Equal Opportunities Commission.

Cheshire, J. (2008). Still a gender biased language? English Today, 24, 7-10. http://dx.doi.org/10.1017/S0266078408000035

Cincotta, M. S. (1978). Textbooks and their influence on sex-role stereotype formation. BABEL: Journal of the Australian Federation of MLTS Associations, 14(3), 24-29

Coates, J., \& Cameron, D. (1998). Women in their Speech Communities. London: Longman.

Coles, G. (1977). Dick and Jane grow up: Ideology in adult basic education readers. Urban Education, 12(1), 37-53. http://dx.doi.org/10.1177/0042085977121003

Crawford, M., \& English, L. (1984). Generic versus specific inclusion of women in language: Effects on recall. Journal of Psycholinguistic Research, 13, 373-381

Crookes, G., \& Lehner, A. (1998). Aspects of process in an ESL critical pedagogy, teacher education course. TESOL Quarterly, 32(2), 319-328

Damen, L. (1987). Textbook Selection and Evaluation. Culture Learning: The Fifth Dimension in the Language Classroom. Addison Wesley, Reading.

Davies, B., \& Harre, R., (1990). Positioning: The discursive production of selves. Journal for the Theory of Social Behavior, 20(1), 43-63. http://dx.doi.org/10.1111/j.1468-5914.1990.tb00174.x

Davis, A., \& Elder, C. (2006). The handbook of Applied Linguistics. Blackwell Publishing

Eckert, P., \& McConnell-Ginet, S. (2003). Language and gender. Cambridge: Cambridge University Press.

Eckert, P. (1989). The whole woman: Sex and gender differences in variation. Language Variation and Change, 1(3), $245-268$ 
Education and Manpower Bureau. (2004). Guiding principles for quality textbooks. [Online] Available: http://www.emb.gov.hk/index.aspx?langno=1\&nodeid=2842 (April 1, 2006)

Equal Opportunities Commission. (2000). Research on content analysis of textbooks and teaching materials in respect of stereotypes: Executive summary. Hong Kong: Hong Kong Printer.

Fairclough, N. (1989). Language and power. New York: Longman.

Fairclough, N. (Ed.). (1992). Critical language awareness. New York: Longman.

Fasold, R. (1990). The sociolinguistics of language. Cambridge, MA.: Basil Blackwell.

Flerx, V. C. et al. (1976). Sex role stereotypes: Developmental aspects and early intervention'. Child Development, 47, 998-1007

Florent, J., \& Walter, C. (1989). A better role for women in TEFL. ELT Journal, 43. Oxford University Press.

Fowler, H. W. (1965). A dictionary of modern English usage (revised by Sir Ernes Gowers). Oxford: Clarendon Press.

Frank, F. W., \& Treichler, P. A. (1989). Language, gender, and professional writing: Theoretical approaches and guidelines for nonsexist usage. New York: The Modern Language Association of America.

Frasher, R., \& Walker, A. (1972). Sex roles in early reading textbooks. The Reading Teacher, 25(8), 741-749

Freeman, R., \& McElhinny, B. (1996). Language and gender. In S. Mckay , \& N. Hornberger (Eds.), Sociolinguistics and language teaching. Cambridge: Cambridge University Press. pp. 218-280

Gaff, Robin. (1982). Sex-stereotyping in modern language teaching - an aspect of the hidden curriculum. British Journal of Language Teaching, 20, 1, 71-78

Gershuny, H. L. (1977). Sexism in dictionaries and texts: Omissions and commissions. In Nilsen, A. P., et al. Sexism and Language. Urbana, Ill: the National Council of Teachers of English.

Goddard, A., \& Patterson, L. (2000). Language and gender. London: Routledge.

Graham, A. (1975). The making of non-sexist dictionary. In B. Thorne, \& N. Henely (Eds.), Language and sex: Difference and dominance. Rowley, M A.: Newbury House Publishers. pp. 57-63

Gupta, A. F., \& Lee, A. S. Y. (1990). Gender representation in English language textbooks used in the Singapore primary schools. Language and Education, 4(1), 29-50. http://dx.doi.org/10.1080/09500789009541271

Guy, G., Horvath, B., Vonwiller, J., Daisley, E., \& Rogers, I. (1986). An intonational change in progress in Australian English. Language in Society, 15(1), 23-52

Halliday, M. (2004). An introduction to functional grammar. London: Arnold.

Halliday, M. A. K. (1978). Language as a social semiotic: The social interpretation of language and meaning. Edward Arnold, London.

Hartman, J., \& E. L. Judd. (1978). Sexism and TESOL materials. TESOL Quarterly, 12, 383-393. http://dx.doi.org/10.2307/3586137

Hellinger, M. (1980). For men must work, and women must weep: Sexism in English language textbooks used in German schools. In C. Kramerae (Ed.), The voices and words of women and men. New York: Pergamon Press. pp. 267-274

Holmes, J., \& Meyerhoff, M. (2003). (Eds.). The handbook of language and gender. Malden, MA: Blackwell.

Holmes, J. (1986). Functions of 'you know' in women's and men's speech. Language in Society, 15(1), 1-22. http://dx.doi.org/10.1017/S0047404500011623

Holmes, J. (2008). An introduction to sociolinguistics. Essex: Pearson Education Limited.

Howe, Florence. (1975). Sexual stereotypes start early. Women and Education, 12, 4, 8-21. http://www.asian-efl-journal.com/march03.sub1.htm

Jaworski, Adam. (1983). Sexism in textbooks. British Journal of Language Teaching, 21, 2, 109-113

Jones, Martha A., Kitetu, Catherine, \& Sunderland, Jane. (1997). Discourse roles, gender and language textbook dialogues: who learns what from John and Sally? Gender and Education, 9, 4, 469-490. http://dx.doi.org/10.1080/09540259721204

Kanemaru, F. (1998). Sexism and Japanese English Textbooks. The Language Teacher, 22, 5

Kang, G. (1989). Putting the migrant back into Adult Migrant Education. Interchange AMES Journal, April, 13 
Kennedy, C., Knowles, M., Caldas-Coulthard, C. R., \& Coulthard, M. (2001). Sociolinguistics. Open Distance Learning Material, CELS. Birmingham: The University of Birmingham.

Key, M. R. (1975). Male/female language. Metuchen, NJ.: The Scarecrow Press.

Kingston, A. J., \& Lovelace, T. (1978). Sexism and reading: A critical review of the literature. Reading Research Quarterly, 13, 133-161

Kyle, D. W. (1978). Changes in basal reader content: Has anyone been listening? The Elementary School Journal, 78, 304-312

Lakoff, R. (1973). Language and woman's place. Language in Society, 2(1), 45-80. http://dx.doi.org/10.1017/S0047404500000051

Lakoff, R. (1975). Language and women's place. New York: Harper and Row.

Law, K. W. K., \& Chan, A. H. N. (2004). Gender role stereotyping in Hong Kong's primary school: Chinese language subject textbooks. Asian Journal of Women's Studies, 10(1), 49-69

Lengermann, P., \& Niebrugge-Brantley, J. (1988). Contemporary feminist theory. In G. Ritzer (Ed.), Sociological theory (2nd edition). New York: Alfred Knopf. pp. 400-443

Lesikin, J. (2001). Determining social prominence: A methodology for uncovering gender bias in ESL textbooks. In D. R. Hall, \& A. Hewings (Eds.), Innovation in English language teaching: A reader. London: Routlege. pp. $275-283$

Linguistic Society of America. (1996). LSA guidelines for nonsexist usage. LSA Bulletin, December 1996, 154

Lock, G. (1996). Functional English grammar: An introduction for second language teachers. Cambridge: Cambridge University Press.

Ma, Kyunghee. (1998). The representation of gender in current ESL reading materials. ORTESOL, 19, 1-22

Macaulay, M., \& Brice, C. (1994). Gentlemen prefer blondes: A Study of gender bias in example sentences. In M. Bucholtz, A. Liang, L. Sutton, \& C. Hines (Eds.), Cultural preferences: Proceedings of the third Berkeley women and language conference. Berkeley Women and Language Group. pp. 449-61

Macaulay, M., \& Brice, C. (1997). Don't touch my projectile: Gender bias and stereotyping in syntactic examples. Language, 73(4), 798-825

Martyna, W. (1980). Beyond the "he/man" approach: The case for nonsexist language. Signs 5, 482-493. http://dx.doi.org/10.1086/493733

McClure, L. J. (1992). Language activities that promote gender fairness. In McCracken, \& Appleby, B. C. (eds.), Gender issues in the teaching of English. Portsmouth, NH: Boynton/Cook Publishers Heinemann.

Mineshima, M. (2008). Gender Representation in an EFL Textbook. [Online] Available: http://www.niit.ac.jp/lib/contents/kiyo/genko/13/14_MINESHIMA.pdf

Montgomery, M. (1995). An introduction to language and society. London: Routledge.

Mukundan, J., \& Nimehchisalem, V. (2008). Gender Representation in Malaysian Secondary School English Language Textbooks. Indonesian Journal of English Language Teaching, 25, 115-136

Nilsen, A. (1977). Sexism in children's books and elementary classroom materials. In A. Nilsen, H. Bosmajian, H. Gershuny, \& J., Stanley (Eds.), Sexism and language. Urbana, Illinois: National Council of Teachers of English. pp. 161-179

Nilsen, A. P. (1971). Women in Children's Literature. College English, 32, 918-926

Nilsen, A. P. et al. (1977). Sexism and language. Urbana, Ill: the National Council of Teachers of English.

O'Barr, W., \& Atkins, B. (1980). Women's language or powerless language? In S. McConnell-Ginet, R., Borker, \& N. Furman (Eds.), Women and language in literature and society. New York: Praeger. pp. 93-220

Ochs, E. (1993). Constructing social identity: A language socialization perspective. Research on Language and Social Interaction, 26(3), 287-306

Oliver, L. (1974). Women in aprons: The female stereotypes in children's readers'. The Elementary School Journal, 74, 253-259. http://dx.doi.org/10.1086/460827

Partridge, E. (1965). Usage and abusage. London: Hamish Hamilton.

Pauwels, A. (1991). Non-discriminatory language. Canberra: Australian Government Publishing Service. 
Pennycook, A. (1990). Towards a critical applied linguistics for the 1990s. Issues in Applied Linguistics, 1, 8-28

Peterson, S. B., \& Lach, M. A. (1990). Gender stereotypes in children's books: Their prevalence and influence on cognitive and affective development. Gender and Education, 2(2), 185-197

Peterson, S., \& Kroner, T. (1992). Gender biases in textbooks for introductory psychology and human development. Psychology of Women Quarterly, 16(1)17-36

Pierce, B. N. (1995). Social identity, investment, and language learning. TESOL Quarterly, 24, 105-112

Porreca, K. (1984). Sexism in current ESL textbooks. TESOL Quarterly, 18, 705-24. http://dx.doi.org/10.2307/3586584

Poulou, S. (1997). Sexism in the discourse roles of textbook dialogues. Language Learning, 15, 68-73

Pugsley, Jenny. (1992). Sexist language and stereotyping in ELT materials: language, bureaucracy and the teacher. Working papers on language, gender and sexism, 2(2), 5-13

Renner, C. E. (1997). Women are "busy, tall and beautiful": Looking at sexism in EFL materials. Paper presented at the National Seminar; Mind the Language (Rome, 1996) and at the annual meeting of TESOL (Orlando, 1997)

Rifkin, B. (1998). Gender representation in foreign language textbooks: A case study of textbooks of Russian. The Modern Language Journal, 82, 217-236

Rovano, M. W. (1991). Preparing for a firefighter's world: How to teach nonsexist language. The English Journal, 80, 59-63. http://dx.doi.org/10.2307/818688

Sadker, M. et al. (1991). The issue of gender in elementary and secondary education. Review of Research in Education, 17, 269-334

Scott, K. P. (1980). Sexist and nonsexist materials: What impact do they have? The Elementary School Journal, 81, 46-52

Scott, K. P. (1981). Whatever happened to Jane and Dick? Sexism in texts re-examined. Peabody Journal of Education, 58, 135-140

Sleeter, Christine E., \& Grant, Carl A. (1991). Race, class, gender, and disability in current textbooks. In M. W. Apple, The politics of the textbook, 78-101

Stevens, K. (1990). World of John and Mary Smith: A study of Quirck and Greenbaum's "University Grammar of English". CLE Working Papers I.

Sunderland, J. (1992). Gender in the EFL classroom. ELT Journal, 46, 11. Oxford University Press.

Sunderland, Jane. (2000). New understandings of gender and language classroom research: texts, teacher talk and student talk. Language Teaching Research, 4(2), 149-173. http://dx.doi.org/10.1191/136216800670214625

Swan, M. (1995). Practical English usage. Oxford: Oxford University Press.

Tannen, D. (1990). You just don't understand: Women and men in conversation. New York: William Morrow.

Thomas, J. (1982). Cross-cultural pragmatic failure. Applied Linguistics, 4(2), 156-185

Thorne, B., \& Henely, N. (1975). Language and sex: Difference and dominance. Rowley, MA.: Newbury House.

Vogli, S. (2009). Gender representation in New Success at First Certificate. Paper submitted to CELS, the University of Birmingham as course requirement for the Degree of Master of Arts in Applied Linguistics. http://www.birmingham.ac.uk/Documents/collegeartslaw/cels/essays/sociolinguistics/SotiVogliSO.pdf

Wajnryb, R. (1996). Death, taxes and jeopardy: Systematic omissions in EFL texts. Oxford University Press, Oxford.

Wallace, C. (1992). Texts and classroom procedures for critical reading. Oxford University Press, Oxford.

Wardhaugh, R. (1998). An introduction to sociolinguistics: 3rd Edition. Oxford: Blackwell Publishers.

Weitzman, L.J. et al. (1972). Sex-role socialization in picture books for preschool children. The American Journal of Sociology, 77, 1125-1150. http://dx.doi.org/10.1086/225261

Wolfson, N. (1989). Language and sex, perspectives: Sociolinguistics and TESOL. Newbury House: New York.

Yoshida, K. et al. (2007). Birdland oral communication Teacher's Book. Tokyo: Buneido. 
Table 1. Book II Visual and Textual Presentations of Males and Females

\begin{tabular}{|l|l|l|l|l|l|l|}
\hline \multirow{2}{*}{ Book II } & \multicolumn{4}{l|l|l|}{ Presentations in Illustrations } & \multicolumn{2}{l|}{ Presentations in Texts } \\
\cline { 2 - 7 } & Total & Male & Female & Total & Male & Female \\
\hline Number & & & & & & \\
\hline Percentage & 65 & 52 & 13 & 405 & 329 & 76 \\
\hline
\end{tabular}

Table 2. Book III Visual and Textual Presentations of Males and Females

\begin{tabular}{|l|l|l|l|l|l|l|}
\hline \multirow{2}{*}{ Book III } & \multicolumn{4}{l|l|l|}{ Presentations in Illustrations } & \multicolumn{2}{l|}{ Presentations in Texts } \\
\cline { 2 - 7 } & Total & Male & Female & Total & Male & Female \\
\hline Number & 59 & 37 & 22 & 229 & 191 & 38 \\
\hline Percentage & 100 & 62.7 & 37.3 & 100 & 83.4 & 16.6 \\
\hline
\end{tabular}

Table 3. Book II Order of Appearance of Males and Females

\begin{tabular}{|c|c|c|}
\hline & Male first & Female first \\
\hline Number & 12 & 2 \\
\hline Instances & $\begin{array}{l}\text { Men and women } \\
\text { Ali and his daughter } \\
\text { The boy and girl } \\
\text { Man and woman } \\
\text { Men and women } \\
\text { Boys and girls } \\
\text { Man and his wife (twice) } \\
\text { Man and his daughter } \\
\text { Hamid and his sister } \\
\text { Jack and his family } \\
\text { Tom and his sister }\end{array}$ & $\begin{array}{l}\text { Girls and boys } \\
\text { Rose and Joe }\end{array}$ \\
\hline
\end{tabular}

Table 4. Book III Order of Appearance of Males and Females

\begin{tabular}{|l|l|l|}
\hline & Male first & Female first \\
\hline Number & 1 & 0 \\
\hline Instances & Men and women & \\
\hline
\end{tabular}


Table 5. Book II Occupations of Male and Female Characters in Texts and Pictures

\begin{tabular}{llll}
\multicolumn{2}{l}{ Males } & Females \\
\hline 1 & engineer & 1 & chemistry teacher \\
\hline 2 & teacher (7 times) & 2 & dress-maker \\
\hline 3 & sailor (twice) & 3 & \\
\hline 4 & photographer (twice) & 4 & \\
\hline 5 & Carpenter & 5 \\
\cline { 2 - 3 } 6 & mechanic (5 times) & 6 \\
\hline 7 & factory worker (5 times) & 7 \\
\hline 8 & Miner (6 times) & 8 \\
\hline 9 & Writer (6 times) & 9 \\
\hline 10 & bus driver (twice) & 10 \\
\hline 11 & doll maker (twice) & 11 \\
\hline 12 & police officer & 12 \\
\hline 13 & doctor & 13 \\
\hline 14 & boss & 14 \\
\hline 15 & animal trainer & 15 \\
\hline 16 & repairman & 16 \\
\hline 17 & thief & 17
\end{tabular}

Table 6. Book III Occupations of Male and Female Characters in Texts and Pictures

\begin{tabular}{llll}
\multicolumn{2}{l}{ Males } & Females \\
\hline 1 & teacher & 1 & nurse (twice) \\
\hline 2 & clerk (three times) & 2 & teacher (three times) \\
\hline 3 & doctor & 3 & doctor \\
\hline 4 & athlete (four times) & 6 & \\
\hline 5 & wrestler (twice) & 7 & \\
\hline 6 & shopkeeper & 8 & \\
\hline 7 & inventor & 9 & \\
\hline 8 & thief (two times) & 10 & \\
\hline 9 & pilot & 11 & \\
\hline 10 & boss & & \\
\hline 11 & hunter & & \\
\hline 12 & police & & \\
\hline 13 & writer & \\
\hline
\end{tabular}


Table 7. Book II Male and Female Activities in Texts and Pictures

\begin{tabular}{llll} 
& Males & & Females \\
\hline 1 & doing the puzzle 2 & 1 & baking a cake 4 \\
\hline 2 & taking the clock apart 2 & 2 & cleaning the rooms \\
\hline 3 & reading newspapers 4 & 3 & watching TV 2 \\
\hline 4 & listening to the news & 4 & working at home \\
\hline 5 & watching TV & 5 & studying 2 \\
\hline 6 & saying prayers & 6 & loosing and finding things \\
\hline 7 & writing a letter 2 & 7 & driving a car \\
\hline 8 & swimming & 8 & crying after a film \\
\hline 9 & studying hard & 9 & doing homework \\
\hline 10 & playing ping-pong 2 & 10 & making tea 2 \\
\hline 11 & playing with the hammer 3 & 11 & cleaning the car \\
\hline 12 & fixing the car 3 & 12 & making a dress working in the kitchen \\
\hline 13 & running & 13 & reading a book 2 \\
\hline 14 & drawing pictures 2 & & \\
\hline 15 & taking pictures & & \\
\hline 16 & riding a bicycle & & \\
\hline 17 & selling a house & & \\
\hline 18 & sending a telegram & & \\
\hline 19 & buying ... 15 & & \\
\hline 20 & helping ... 3 & & \\
\hline 21 & parking the car & & \\
\hline 22 & repairing the bicycle & & \\
\hline 23 & finding a new job & playing football 3 & \\
\hline 25 & listening to tapes & \\
\hline & & & \\
\hline 24 & & \\
\hline
\end{tabular}


Table 8. Book III Male and Female Activities in Texts and Pictures

\begin{tabular}{llll} 
& Males & & Females \\
\hline 1 & playing & 1 & watching TV \\
\hline 2 & swimming 2 & 2 & studying 4 \\
\hline 3 & washing the car 3 & 3 & making a dress \\
\hline 4 & studying 2 & 4 & making cakes \\
\hline 5 & fixing the car & 5 & making the tea \\
\hline 6 & buying .. 3 & 6 & cooking the dinner \\
\hline 7 & helping the others & 7 & watching cartoons 2 \\
\hline 8 & reading 6 & 8 & playing ping-pong \\
\hline 9 & driving a car & 9 & writing letters \\
\hline 10 & playing ping-pong 3 & 10 & drawing pictures \\
\hline 11 & watching cartoons & 11 & washing the clothes 2 \\
\hline 12 & listening to the radio 2 & & \\
\hline 13 & brushing the teeth & & \\
\hline 14 & playing football 3 & & \\
\hline 15 & watching a film & & \\
\hline 16 & doing homework & & \\
\hline 17 & taking pictures & & \\
\hline 18 & writing books & & \\
\hline 19 & drawing pictures & & \\
\hline 20 & climbing trees & & \\
\hline 21 & painting & washing up & \\
\hline 22 & washing the dishes & \\
\hline 24 & watching TV 2 & \\
\hline & & \\
\hline 23 & & \\
\hline
\end{tabular}

